\section{B. Bhengu \\ M. Bussin}

The perceived effectiveness of employee share options as a mechanism of talent management in South Africa

\title{
THE PERCEIVED EFFECTIVENESS OF EMPLOYEE SHARE OPTIONS AS A MECHANISM OF TALENT MANAGEMENT IN SOUTH AFRICA
}

\author{
Mthunzi Bhengu: Dept of Industrial Psychology \& People Management: University of \\ Johannesburg \\ Mark Bussin: Dept of Industrial Psychology \& People Management: University of Johannesburg
}

PURPOSE OF THE STUDY: The purpose of the study was to explore the views of a sample of employees, industry experts, academics, and professionals to determine whether employee share options (ESO) are an effective talent management tool in the South African context. Talent management refers to the attraction, motivation, and retention of employees, as well as fostering their loyalty to the company.

PROBLEM INVESTIGATED: This study sought to explore and provide empirical evidence as to whether or not ESO are an effective talent management strategy and remuneration tool.

DESIGN AND METHODOLOGY: A quantitative research design was used for this study. A survey was constructed by the researchers, using the main themes identified in the literature. A purposive sampling methodology was then employed, using the key informant technique. A total of 4300 surveys were electronically distributed, and 256 completed surveys were received. Data were analysed using descriptive statistics.

FINDINGS: This study suggests that while ESO are seen as an important component of a total reward solution, they are not the primary drivers of the attraction, retention, and motivation of talent. Respondents indicated that the quality of the work environment and the presence of developmental opportunities are far more significant considerations. . Furthermore, the majority of respondents (41\%) indicated that they would prefer the allocation of share options to correspond with individual performance.

VALUE OF THE RESEARCH: The study suggests that employee reward preferences have evolved over time. Whilst ESO may have been considered a pivotal component of talent management in the late 1990s, today they are only a component of an expected total reward solution. The study demonstrates the importance of consistently reviewing the employee value proposition to ascertain the changing preferences of employees in order to accordingly adapt and maximise talent management. The study can be used as guidance in the design and implementation of share schemes.

CONCLUSION: This study suggests that while ESO are perceived as an important component of a total reward solution, these are not the primary drivers of the attraction, retention, and motivation of talent. Respondents indicated that the quality of the work environment and the availability of developmental opportunities are far more significant considerations. The findings suggest that employee reward preferences have evolved over time. Today's employee has a desire to have reward linked to individual performance, which implies that employers will have to revisit their reward solutions as part of their total value proposition.

KEY WORDS: Employee share options; talent management; reward strategies; employee perceptions; quality working environment; developmental opportunities; South Africa. 


\section{B. Bhengu \\ M. Bussin}

The perceived effectiveness of employee share options as a mechanism of talent management in South Africa

\section{INTRODUCTION}

As traditional sources of competitive advantage such as financial capital, technology, and location become more easily accessible and less significant, companies are increasingly relying on human capital as a key source of differentiation. The demand for talent exceeds the supply, and the global war for talent wages on. Kuptsch and Fong (2006) assert that companies that ignore the importance of talent as a key competitive differentiator are likely to become 'emigration nurseries.' The key to success in global markets is widely accepted as the capability to recruit and retain skilled personnel (Rosen, Case \& Staubus, 2005a).

There is a large body of literature on talent management, which includes a multitude of theories and models on the best ways to attract, retain, reward, and motivate talent (inter alia Mariott, 2001; Morton, 2005; Faragher, 2006; Vohra, 2006; Cunningham, 2007b; Rueff, 2008; Wellins, Smith, Paese \& Erkel, 2008). Talent management is defined by Rice (2007:2) as "the systematic attraction, identification, development, engagement/retention and deployment of those individuals with high potential who are of particular value to an organisation." The focus of the research described in this article is the management of talent, with specific reference to reward and employee share options (ESO).

The use of ESO as part of corporate remuneration schemes and talent management strategies has become commonplace (Leape, 2006). Historically, ESO plans were seen as a way to maximise shareholder value by creating a cadre of motivated employees with a personal stake in the success of the company (Martin, 2006). Of late, the lure of ESO has declined, and management is being challenged to revisit the basics of the company's employee value propositions to drive engagement and increase retention (Martin, 2006).

Share options are often seen as a drawcard for talent by many large and talent-orientated companies. Martin (2006) states that numerous young executives prefer this type of remuneration to traditional pension funds. Despite the stated preference for non-salary benefits, such as ESO, the assertion of their efficacy in driving performance and improving retention remains contentious.

Martin (2006) asserts that gestures such as the recognition of good work are more effective than slightly higher salaries in driving employee engagement. This finding was reinforced in a more recent study (Hughes, 2008), which found that salary-based strategies are less effective than career development strategies in retaining employees. $64 \%$ of participants surveyed indicated that non-salary benefits, such as ESO, are an effective means of employee retention (Hughes, 2008).

Casey (2002) contends that one of the disadvantages of share options is that they tend to lose their effectiveness outside the executive arena. The reason for this is that companies comprise many divisions but have only one share price. Employees want to be rewarded on their own merits and efforts, rather than on the basis of conflicting inputs from other employees and market forces. In addition, to benefit from share options, employees are usually induced to remain with a company for an extended tenure (Hall \& Murphy, 2003). Although this strategy may lead to increased retention, there is also the risk of the share options being viewed as the proverbial 'golden handcuffs' that limit career mobility, leading to resentment.

Proponents of ESO believe that these serve as a critical component of participative management, where employees and management work as a team. Employees strive to achieve a set of organisational goals in exchange for collective, promised rewards (Bussin \& Thomson, 2000). Gilbert (2005) and the New Brunswick Innovation Foundation (2006) highlight potential benefits accruing from an ESO plan to the company, employees, and the shareholders. These potential benefits are described in Table 1. 
Table 1. Benefits of ESO Plans

\begin{tabular}{|c|c|c|}
\hline \multicolumn{3}{|c|}{ Benefits of Employee Share Option Plans } \\
\hline Company Benefits & Shareholder Benefits & Employee Benefits \\
\hline $\begin{array}{l}\text { - Create a culture of } \\
\text { ownership and } \\
\text { accountability amongst } \\
\text { employees } \\
\text { - Recognise and value the } \\
\text { contribution of employees } \\
\text { - Boost productivity and } \\
\text { competitiveness } \\
\text { - Improve tax treatment, } \\
\text { including tax deductable } \\
\text { dividends } \\
\text { - Decrease reliance on cash } \\
\text { flow to meet monthly salary } \\
\text { bill } \\
\text { - Enhances attraction, } \\
\text { retention, and motivation of } \\
\text { employees } \\
\text { Can be used as an exit } \\
\text { strategy for company } \\
\text { owners }\end{array}$ & $\begin{array}{l}\text { - Increase the value of the } \\
\text { company, as employees } \\
\text { have a vested interest in } \\
\text { overall company success } \\
\text { - Create an opportunity to } \\
\text { create long-term, capital- } \\
\text { based wealth among } \\
\text { employees } \\
\text { - Increase returns, as } \\
\text { shareholders' interests are } \\
\text { in line with those of } \\
\text { employees } \\
\text { - Create liquidity at fair } \\
\text { market value } \\
\text { - Maintain organisational } \\
\text { control }\end{array}$ & $\begin{array}{l}\text { - Allow employees to share } \\
\text { directly in the equity growth } \\
\text { of the company } \\
\text { - Motivate and build unity } \\
\text { and team spirit } \\
\text { - Allow employees to feel } \\
\text { 'connected' to the business } \\
\text { - Create an opportunity for } \\
\text { employees to earn more } \\
\text { than their annual salaries if } \\
\text { the company performs well } \\
\text { - Serve as a type of savings } \\
\text { plan and/or investment } \\
\text { - Allow employees to delay } \\
\text { paying taxes on the stock } \\
\text { they own until the shares } \\
\text { are sold }\end{array}$ \\
\hline
\end{tabular}

\section{STUDY OBJECTIVES}

The primary objective of the research presented in this article was to explore the views of a sample of employees, industry experts, academics, and professionals to determine whether ESO are an effective talent management tool in the South African context. Talent management includes the attraction, motivation, and retention of employees, as well as fostering their loyalty to the company.

\section{METHODOLOGY}

\section{Research Design}

A quantitative research design was used for this study. A survey was designed by the researchers, using the main themes identified in the literature. Completion of the survey was voluntary, and all surveys were anonymous. The confidentiality of all information supplied by respondents was maintained, and there were no material ethical concerns. Data were analysed by means of descriptive statistics.

\section{Research Sample and Data Collection}

A purposive sampling methodology was employed, using the key informant technique. The survey was distributed to 300 University of Johannesburg master's students from the classes of 2006, 2007, 2008, and 2009, as well as approximately 4000 employees of client companies of 21 st Century Pay Solutions (a consultancy based in Gauteng, South Africa). A total of 4300 surveys were electronically distributed through STATKON (a statistics consultancy based at the University of Johannesburg). Respondents were given five working days to complete the survey. A total of 256 completed surveys were received - a $17 \%$ response rate. 
M. B. Bhengu

M. Bussin

\section{Research Instrument}

A research survey comprising a mixture of 21 closed- and open-ended questions was constructed from the results of the literature review. The survey was divided into three sections, namely background information, reward preferences, and talent management. The survey was administered electronically to all prospective respondents.

\section{ANALYSIS AND INTERPRETATION OF FINDINGS}

\section{Demographic Characteristics}

The demographic characteristics of the sample are described in Table 2 below.

Table 2. Demographic Characteristics of the Sample

\begin{tabular}{|c|c|c|}
\hline \multicolumn{3}{|c|}{ Demographic Characteristics of the Sample, $n=256$} \\
\hline Demographic Characteristic & Frequency & Percentage \\
\hline \multicolumn{3}{|l|}{ Gender } \\
\hline Male & 143 & $56 \%$ \\
\hline Female & 113 & $44 \%$ \\
\hline \multicolumn{3}{|l|}{ Age } \\
\hline $18-25$ & 2 & $1 \%$ \\
\hline $26-40$ & 122 & $48 \%$ \\
\hline $41-50$ & 74 & $29 \%$ \\
\hline $51-60$ & 53 & $20 \%$ \\
\hline 61 and older & 5 & $2 \%$ \\
\hline \multicolumn{3}{|l|}{ Ethnicity } \\
\hline Black & 92 & $36 \%$ \\
\hline White & 125 & $49 \%$ \\
\hline Coloured & 19 & $7 \%$ \\
\hline Indian & 1 & $0.4 \%$ \\
\hline Asian & 19 & $7 \%$ \\
\hline \multicolumn{3}{|l|}{ Level of Seniority } \\
\hline Management & 84 & $33 \%$ \\
\hline Senior management & 64 & $25 \%$ \\
\hline Executive & 89 & $34 \%$ \\
\hline Other & 19 & $8 \%$ \\
\hline \multicolumn{3}{|l|}{ Level of Education } \\
\hline Matric & 15 & $6 \%$ \\
\hline Certificate or diploma & 41 & $16 \%$ \\
\hline Postgraduate degree & 136 & $53 \%$ \\
\hline Other & 64 & $25 \%$ \\
\hline \multicolumn{3}{|l|}{ Tenure with Current Employer } \\
\hline $0-3$ years & 64 & $25 \%$ \\
\hline $4-6$ years & 44 & $17 \%$ \\
\hline 6 years + & 148 & $58 \%$ \\
\hline
\end{tabular}

Of the respondents, $56 \%$ were male and $44 \%$ were female. The majority (48\%) of respondents were between 26 and 40 years of age. In terms of ethnicity, $49 \%$ of the respondents were white and $36 \%$ were black. This accurately reflects the current South African corporate reality, where white South Africans still dominate the gender distribution of board members. All respondents indicated that they are in management, senior management, or executive positions. The remaining $8 \%$ indicated that they are specialists, retired executives, non-executive directors, consultants, or proprietors. 
The industry profile of the sample is illustrated in Figure 1 below.

Figure 1. Industry Profile of Respondents

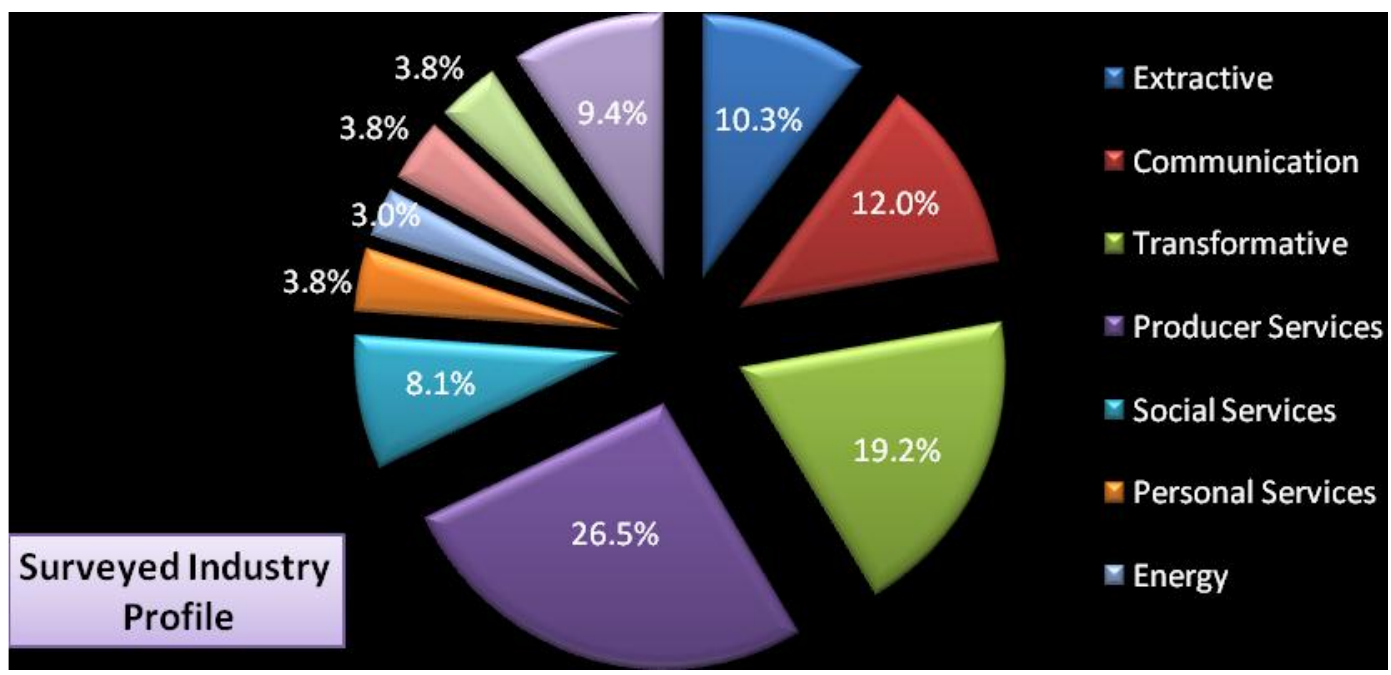

The sample for this study comprised a broad spectrum of sectors. The $9.4 \%$ of respondents who indicated "Other" sectors or industries fell under the producer services industry, as they include communication, retail, research, and skills development. The industry profiles are described in Table 2.

Table 2: Description of Industry Profiles

\begin{tabular}{|l|l|}
\hline Description of Industry Profiles \\
\hline Industry Profile & Description \\
\hline Extractive & Agriculture, forestry and paper, mining, oil, and gas \\
\hline Transformative & $\begin{array}{l}\text { Construction and building, utilities and energy, and manufacturing } \\
\text { (food, textiles, metal, electrical, machinery, chemicals, } \\
\text { pharmaceutical, automobiles, and miscellaneous) } \\
\text { Banking and financial services, insurance, real estate, engineering, } \\
\text { accounting, consulting, legal, and miscellaneous business services }\end{array}$ \\
\hline Producer services & $\begin{array}{l}\text { Medical and health, hospital, education, welfare and religious, } \\
\text { postal, and government, as well as non profit organisations, state- } \\
\text { owned enterprises and parastatal regulators, and miscellaneous } \\
\text { social services }\end{array}$ \\
\hline Social services & $\begin{array}{l}\text { Domestic, hotel, food and beverages, repair, laundry, barber and } \\
\text { salon, entertainment and leisure, media and advertising, and } \\
\text { miscellaneous personal services }\end{array}$ \\
\hline Personal services & Transportation, logistics, communication, wholesale, and retail \\
\hline Distributive services
\end{tabular}

\section{Importance of ESO}

Only $39 \%$ of respondents regarded the share option schemes offered by their companies as a preferred reward. The analysis of data revealed that, although ESO schemes exist in organisations, they are not as preferred as (i) developmental opportunities, (ii) salary, and (iii) a quality working environment. In fact, ESO as a reward was ranked last as a tool with which to retain and attract talent. It is also interesting to note that ESO were considered more effective in retaining employees than in attracting talent. The comparison of reward preferences is illustrated graphically in Figure 2. 
M. B. Bhengu

M. Bussin
The perceived effectiveness of employee share options as a mechanism of talent management in South Africa

Figure 2: Reward Preferences

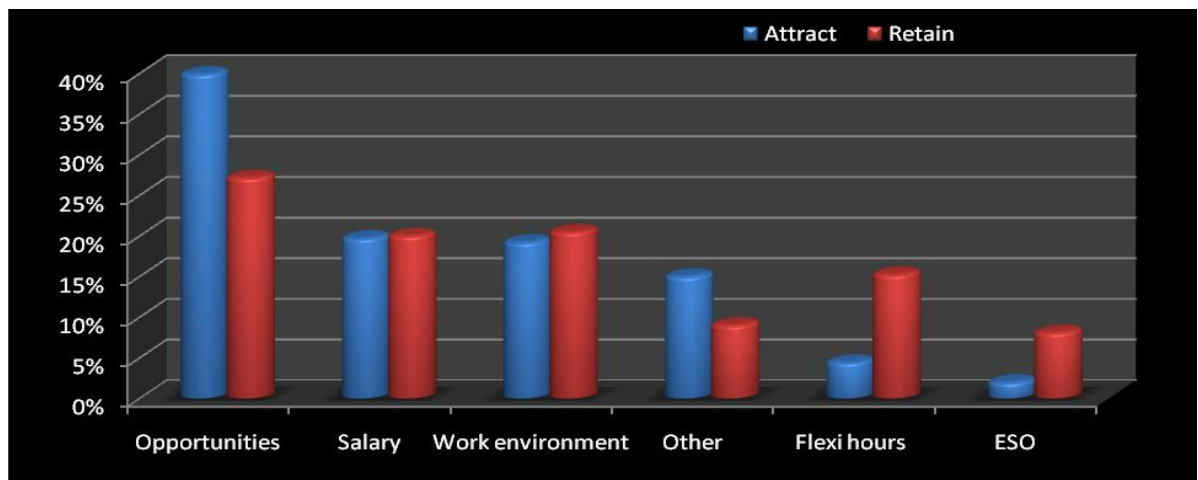

Despite the fact the ESO were ranked as the least preferred reward, $82 \%$ of the respondents indicated that share options are an important reward mechanism.

Figure 3. Perceived Importance of ESO

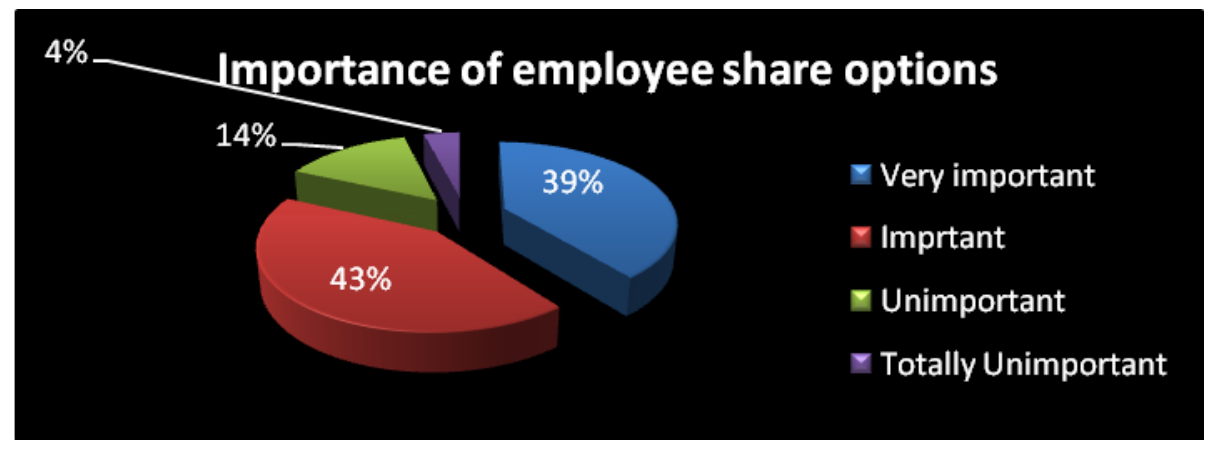

No significant relationship was found between the importance of EOS as a talent management strategy and the age, tenure with current employer, level of seniority, or industry profile of the respondents.

\section{ESO and Talent Management}

$82 \%$ of the respondents indicated that share options are an important part of a talent management strategy. In order to determine whether employee share options contribute to the attraction of talent, respondents were asked to indicate which of the factors listed in Table 3 (below) attracted them to their current employer. Respondents were requested to select only one factor.

\section{Table 3: Factors that Attracted Respondents to Current Employer}

\begin{tabular}{|l|l|}
\hline Developmental opportunities & $40 \%$ \\
\hline Quality work environment & $24 \%$ \\
\hline Monthly salary & $20 \%$ \\
\hline Other, please specify & $10 \%$ \\
\hline Other benefits (medical, pension, etc.) & $4 \%$ \\
\hline Employee share options & $2 \%$ \\
\hline
\end{tabular}

Only $2 \%$ of the respondents indicated that they were attracted by ESO to join their current employers. $40 \%$ of the respondents cited developmental opportunities and $24 \%$ cited working environment as the main sources of attraction. This finding supports the research conducted by Vaknin (2002), which found 


\section{B. Bhengu \\ M. Bussin}

The perceived effectiveness of employee share options as a mechanism of talent management in South Africa

that ESO have lost their magnetism. This presents a challenge to management and companies to revisit the basics of what makes them attractive to desirable employees.

To assess whether ESO contribute to the retention of talent, respondents were asked to indicate which of the factors listed in Table 4 (below) encourage them to stay with their current employers. Respondents were requested to select only one factor.

\section{Table 4: Factors that Encourage Respondents to Remain with Current Employers}

\begin{tabular}{|l|l|}
\hline Quality work environment & $36 \%$ \\
\hline Developmental opportunities & $27 \%$ \\
\hline Monthly salary & $20 \%$ \\
\hline Employee share options & $8 \%$ \\
\hline Other, please specify & $6 \%$ \\
\hline Other benefits (medical, pension, etc.) & $3 \%$ \\
\hline
\end{tabular}

Only $8 \%$ of the respondents cited ESO as the reason why they are encouraged to stay with their current employer. A quality work environment and developmental opportunities far exceeded ESO in terms of perceived retention value.

To assess the significance of ESO in motivating work performance, respondents were asked to indicate which one of the factors listed in Table 5 they considered to be the greatest motivator of work performance.

Table 5: Factors Considered the Greatest Motivators of Work Performance

\begin{tabular}{|l|l|}
\hline Quality work environment & $33 \%$ \\
\hline Developmental opportunities & $29 \%$ \\
\hline Monthly salary & $18 \%$ \\
\hline Employee share options & $11 \%$ \\
\hline Other, please specify & $8 \%$ \\
\hline Other benefits (medical, pension, etc.) & $1 \%$ \\
\hline
\end{tabular}

$11 \%$ of the respondents indicated that ESO motivate them to perform at their best, while $33 \%$ cited working environment and $29 \%$ cited developmental opportunities.

\section{Allocation of ESO}

Respondents were asked how they would prefer ESO to be allocated. Table 6 presents their preferences.

Table 6. Preferences Regarding Allocation of ESO

\begin{tabular}{|l|l|}
\hline Linked to individual's performance & $41 \%$ \\
\hline Linked to company's performance & $38 \%$ \\
\hline Linked to my team's performance & $12 \%$ \\
\hline Other, please specify & $9 \%$ \\
\hline
\end{tabular}

The majority of respondents preferred share options to be linked to individual (41\%) or company (38\%) performance. ESO are usually linked to the company's share performance on the stock market. In this way, reward is linked, not only to individual performance, but to externalities and market forces that are beyond the control of the company or any individual. 


\section{B. Bhengu \\ M. Bussin}

The perceived effectiveness of employee share options as a mechanism of talent management in South Africa

The findings reveal that only $48 \%$ of respondents prefer a shorter vesting period. This could suggest that these respondents are satisfied with other reward solutions offered by their employers.

\section{GENERALISATIONS FROM THE STUDY}

This study suggests that while ESO are seen as an important component of a total reward solution, they are not the primary drivers of the attraction, retention, and motivation of talent. Respondents indicated that the quality of the work environment and the presence of developmental opportunities are far more significant considerations. One of the reasons for this could be the fact that ESO are usually linked to company performance, which has a locus of control that is external to the employee. Reward is thus not based on individual performance, but on numerous factors that are within the control of neither the individual nor the company. This rationale is supported by the fact that the majority of respondents $(41 \%)$ stated they would like their share options to be linked to individual performance.

\section{CONCLUSION}

The purpose of this research study was to explore the views of a sample of employees, industry experts, academics, and professionals to determine whether ESO are an effective talent management tool in South Africa. A survey was designed using themes from the literature and distributed to a potential sample of 4300 respondents. 256 completed surveys were received. The findings suggest that employee reward preferences have evolved over time. Whilst ESO may have been considered a pivotal component of talent management in the late 1990s, today they are only a component of an expected total reward solution. A quality work environment and developmental opportunities were found to be far more significant drivers of the attraction, motivation, and retention of talent than the offer of ESO. It is suggested that one of the main reasons for this is the employees' desire to have reward linked to individual performance.

\section{REFERENCES}

Bussin, M. \& Thomson, D. 2000. Wealth sharing for all South Africans. People Dynamics, 130(28):32-35.

Casey, M. 2002. Stock option didn't work: what will? Wall Street Journal-Eastern Edition, 240(40):33.

Cunningham, I. 2007b. Talent management: making it real. Development and Learning in Organizations, 21(2):12.

Faragher, J. 2006. Talent Management Strategy: Spotlight on talent. Personnel Today, 8(3):12-13.

Gilbert, R.J. 2005. The potential advantages of an employee stock ownership plan (ESOP). Accessed: 02 April 2009, available at: http://www.ncpanet.org/pdf/2006fl_esop.pdf.

Hall, B.J. \& Murphy, K.J. 2003.The Trouble with Stock Options. Journal of Economic Perspectives, 17(3):129-147.

Hughes, B. 2008. What Will It Take to Keep our Best People? Institute for Sustainable Leadership, Macquarie Graduate School of Management, 1-7.

Kuptsch, C. \& Fong, P. 2006. Competing for global talent in an age of turbulence. International Labour Office: Geneva.

Leape, E. 2006. Managing the Skills Shortage. Canadian Manager, Winter, 4-7.

Martin, P. 2006. Competing for Global Talent - The US Experience, ILO, IILS. 
M. B. Bhengu

M. Bussin
The perceived effectiveness of employee share options as a mechanism of talent management in South Africa

Morton, L. 2005, Talent Management Value Imperatives: Strategies for Successful Execution, Conference Board, Research Report.

Peters, K. 2007. Passive jobseekers solution to labour woes. Canadian HR Reporter, 20(13):18.

Rice, P. 2007. Is talent management really important? Training Zone, 16(3):1-3.

Rosen, C., Case, J. \& Staubus, J. 2005a. When employees have equity attitude. Harvard Business School Working Knowledge Series, 34(7):23.

Rueff, R. 2008. What is the talent brand? Talent force, 89(3):23-34.

Vaknin, S. 2002.Employee benefit and ownership. Accounting Review, 52(3):40-50.

Vohra, K. 2006. System approach to retention of critical employees. Rai University, India.

Wellins, S.R., Smith, A.B., Paese, M.J. \& Erkel, S. 2008. Nine best practices for effective talent management. Developmental Dimensions International.

Zikmund, W.G. 2003. Business research methods. Oklahoma State University: South-Western. 